УДК 017.4:378.091.3

DOI:

Ольга Стрілець, кандидат педагогічних наук, доиент кафедри мистеиьких дисичилін і методик навчання ДВНЗ “Переяслав-Хмельницький державний педагогічний університет імені Григорія Сковороди"

Марта Генесіран, викладач кафедри мистецьких дисциплін $і$ методик навчання ДВНЗ “Переяслав-Хмельницький державний педагогічний університет імені Григорія Сковороди”

\title{
“КОЛЬОРОЗНАВСТВО" У ПРОФЕСІЙНОМУ СТАНОВЛЕННІ МАЙБУТНЬОГО УЧИТЕЛЯ МИСТЕЦЬКИХ ДИСЦИПЛІН
}

У статті висвітлено особливе значення навчальної дисиипліни “Кольорознавство”, яка сприяє професійному становленню майбутніх учителів мистеиьких дисичилін. На основі аналізу наукових літературних джерел особливостей кольору в образотворчому мистецтві та вивчення передового педагогічного досвіду окреслено основні якості кольоруїх роль у підготовиі майбутнього фахівия. Визначено наукові підходи у навчальному прочесі “Кольорознавство”. Таким чином, вивчення “Кольорознавство” $\epsilon$ основною навчальною дисиипліною у професійному становленні майбутнього учителя мистецьких дисциплін.

Ключові слова: колір; майбутні фахівиі; “Кольорознавство”, змістова наповненість; мистецькі дисцииліни; наукові підходи.

Jim. 8.

Olha Strilets, Ph.D.(Pedagogy), Associate Professor of the Artistic Disciplines and Teaching Methods Department, SHEI "Pereyaslav-Khmelnytsky Hryhoriy Skovoroda State Pedagogical University"

Marta Henesiran, Lecturer of the Artistic Disciplines and Teaching Methods Department, SHEI "Pereyaslav-Khmelnytsky Hryhoriy Skovoroda State Pedagogical University

\section{"COLOROLOGY" IN THE PROFESSIONAL FORMATION OF A FUTURE ARTISTIC DISCIPLINES TEACHER}

In the article it is highlighted the special significance of the educational discipline "Colorology", which promotes the professional formation of future artistic disciplines teachers.

Based on the analysis of scientific literary sources on color features in fine art and the study of advanced pedagogical experience the main color qualities and their impact on a future specialist training are outlined. It is found that studying of color features is a universal benchmark that not only affects a human psychological condition, but also is an important discipline in future artistic disciplines teacher professional training.

It is emphasized that the color is one of the main means of fine and decorative-applied art, as well as an important ideological and artistic and expressive means. It is accented that in various historical periods a certain color palette is used, which affects the educational process of fine arts disciplines.

It is defined the scientific approaches in the educational process "Colorology", namely: 1) an axiological approach that is used in acquiring skills based on the tradition of a certain discipline; 2) a systematic approach that provides consideration of future artistic disciplines teachers training as a coherent system; 3) competent approach, which provides the formation of students' capabilities for competent implementation of artistic and pedagogical activity; 4) an integrative approach that provides conceptual connections between different knowledge spheres; 5) a creative approach that provides for the organization of future teachers training from a substantivecontent aspect to the student's identity.

Summarizing the foregoing, it should be stated that "Colorology" is a major academic discipline in future artistic disciplines of teacher's professional formation, such as: "Painting", "Decorative and applied art", "Ethnodesign", "Fundamentals of clothes modeling", "Interior design" and "Floristic design".

Keywords: color; future specialists; "Colorology"; content; artistic disciplines; scientific approaches.

П остановка проблеми. Входження нашого суспільства у світовий освітній простір потребує суттєвих змін інноваційного спрямування у підготовці майбутнього учителя мистецтва. Головним завданням мистецької освіти $\epsilon$ перегляд концептуальної системи поглядів на професійну освіту у вищий школі і зміцнення уваги дослідників до особистості майбутнього учителя, його професійного становлення. 
Проблема, що стосуються розуміння кольорових співвідношень, їх гармонійного поєднання, сприйняття, особливостей впливу на стан людини, передбачає символічне значення у мистецтві різних часів і культур, завжди буде актуальною і цікавою у світі мистецтва, зокрема, для майбутніх фахівців мистецьких дисциплін. За твердженням науковця Б. Губаля: “Колористичні закономірності поруч з глибоко особистим, суб'єктивним сприйняттям їх кожним художником мають також культуру, історичну основу, яка визначає притаманні тому чи іншому історичному періодові, тій чи іншій культурній спільноті символіку кольору і кольорові співвідношення, а також соціальну психологію їх сприйняття" [3]. Кольорознавство як наука має надзвичайно велике значення в образотворчому та декоративноприкладному мистецтві, позаяк саме колір є один 3 найпотужніших засобів творення художньої форми [7].

Аналіз останніх досліджень і публікацій. Питання колірних ознак обсервували відомі вітчизняні і зарубіжні лінгвісти, педагоги, філософи та психологи: С. Алєксєєв, Н. Бахіліна, Б. Берлін, Е. Бош, Р. Будагов, О.Веселовський, Л. Виготський, И. Гете,В.Кандинський,Р.Кей,Р.Назар'ян,Н.Пєлєвіна, В. Петренко, С. Рубінштейн, С. Соловйов, Б. Шабоук, таін. Семантикукольороназв досліджували 3. Вердієва, Я. Бистров, О. Крижанська та інші.

Отже, метою статті є розкриття особливого значення навчальної дисципліни “Кольорознавство”, яка сприяє професійному становленню майбутніх учителів мистецьких дисциплін.

Виклад основного матеріалу. Реформування мистецької освіти в Україні неможливо здійснити без фахової підготовки майбутніх учителів мистецьких дисциплін. Вивчення навчальних дисциплін 3 образотворчого мистецтва посідає одне з важливих місць у вищий системі навчання. Спираючись на провідні положення сучасної педагогіки вищої школи, нами розглянуто змістову наповненість 3 навчальної дисципліни “Кольорознавство”.

Колір - один з основних засобів образотворчого та декоративно-прикладного мистецтва, що відображає у поєднанні зі світлотінню, світловий тон предмета, забарвлення; якість окремого кольорового тону в ансамблі художнього твору або мотиву. А колорит це - гармонійне поєднання кольорів як один із засобів зображення дійсності розкриття змісту твору в живописі та декоративно-ужитковому мистецтві. Колорит $є$ одним 3 найважливіших художніх засобів емоційного впливу на глядача. Колорит може будуватись на поєднанні локальних кольорів і на тонких тональних сполученнях [4].
Науковець сучасності Т. Печенюк визначає поняття “колір” як “відчуття, що виникає в мозку у відповідь на те світло, яке відбивалось від певної поверхні та потрапило на сітку ока" [7].

Колір $є$ важливим ідейно-художнім i виражальним засобом. На думку дослідника О. Крижанської, “колір - це абстрагована і усвідомлена та загальна сторона предмета, яка в ньому знаходить здійснення, але не належить йому неодмінно i, як загальне, може належати всякому явищу чи предмету. Не існуючи сам по собі, колір обов'язково позначається в предметі і може переноситися 3 предмета на предмет, у чому проявляється його загальне значення" [6, 22-24].

Колір - це властивість поверхні предмета “сортувати” промені світла, що падають на неї, та відбивати другорядне випромінювання від своєі поверхні. 3 цього приводу науковець С. Прищенко стверджує, що “поверхні, які поглинають та відбивають довгохвильові промені називають хроматичними. Поверхні, які рівномірно поглинають та відбивають промені всіх довжин хвиль називають ахроматичними. Світлість кольору є хроматичний, а ступінь різниці визначеного кольору від чорного або білого ахроматичний” [8].

Історичні факти свідчать, що в епоху Стародавньої Греції класифікували кольори за основою міфологічних традицій: світла і темряви. В цей період храми були розмальовані восковими фарбами: червоного, синього, жовтого, блакитного та зеленого кольорів. Пізніше, з римських часів, майстри використовували і позолоту.

В епоху античної культури, зокрема критяни, фарбували у червоний колір глиняні стіни житлових будинків. У ті часи не лише у палацах, а й у звичайних будинках стіни вкривалися розписами, що передавали безпосереднє емоційне враження від дійсності. Це засвідчують фрагменти фрески iз зображенням лілей із вілли Амнісосі з рожевопурпуровими, жовно-зеленими, жовтувато-сірими та білими площинами вибагливої форми.

За дослідженнями науковців, критські майстри не наслідували реальних кольорів зображуваного, у їхній кольоровій гамі закладено дивовижне відчуття емоційного впливу кольору на людину. Тому часто тіло людини чи тварини могло зображуватись блакитним, скелі - жовтими, а рослини - червоними. Яскравою особливістю декоративно-прикладного мистецтва критян стало винайдення фаянсу і виготовлення з нього ваз у стилі “камарес". Ці творіння розписані білою або жовтувато-білою і червоною фарбою двох відтінків на блискучому чорному тлі або чорною 
і червоною - на білому. Критські майстри вперше використали фреску з розписом на вологому тлі, що забезпечило добре збереження фарб. За словами науковців, майстри Криту створювали неймовірні декоративні розписи, знаючи лише п’ять фарб - чорну, білу, блакитну, жовту, червону [1].

У науковій праці “Кольорознавство” дослідник С. Прищенко схематично поділяє процес розвитку уявлень кольору на такі етапи:

1. Первісне суспільство. Цей період передбачав міфологізацію та наближення кольорів із важливими речами й стихіями.

2. Рання історія. В цю епоху використання певного кольору призначалося для діагностики хвороб і різних небезпек.

3. Епоха Античності (3000 p. до н.е. -400 р. н.е.). У цей період створювалась міфологія колірних відношень.

4. Епоха Середньовіччя (XII-XV ст.), яка передбачала колірну семантику за релігійними канонами.

5. Епоха Відродження (XV-XVII ст.), яка втратила символічне значення кольору і створила “практично-живописні” системи кольорів.

6. Епоха Просвітництва (XVII-XVIII ст.), яка передбачала систему природничо-наукової класифікації кольорів. На цьому етапі створили систему психофізіологічної основи, згідно 3 враженнями від кольорів: трикомпонентну теорію колірного зору, тривимірне представлення кольору, фізіологічне представлення 3-х основних кольорів для оптичного змішування.

7. Епоха XX - поч. XXI ст. Цей період передбачає диференціацію колірних систем, залежно від практичного застосування [8].

Доведено, що у професійному становленні майбутнього учителя мистецьких дисциплін $\epsilon$ навчальна дисципліна “Декоративно-прикладне мистецтво”, в якій використовується символічні кольори. Це стосується і орнаментики українського декоративно-прикладного мистецтва.

Традиційно вишиванка білого кольору означає чистоту, невинність, непорочність, адже в давнину їх носили молоді, незаміжні дівчата. Чорний колір орнаменту вишиванки асоціюється $з$ гарним врожаєм, обіцяє власнику багатство та благополуччя. Використання синього кольору на українських вишиванках вважали символом неба і води, душевного спокою, лікування від хвороби. Орнамент синім кольором застосовується на чоловічих вишиванках, тому що, саме чоловіки захищали родину від небезпек. Червоний колір символізує сонце, любов, радість, тому орнамент дитячих і жіночих вишиванок прикрашають червоними нитками. Зелений колір асоціюється 3 молодістю, красотою. Вважали, що застосування зеленого кольору в орнаменті рятує від природних стихій. Золотий або жовтий - це символ меду і пшениці, добробуту. Вишиванки з золотим i жовтим орнаментом передбачають в родині матеріальний достаток.

Отже, означені кольори вважаються традиційними для вишивки українського одягу та аксесуарів і називаються багатобарвними орнаментами. Орнамент кожної області України несе змістову наповненість, адже за їх допомогою вітчизняні майстри створюють унікальні речі.

Важлива роль у декоративно-ужитковому мистецтві України належить писанкарству. Цей вид образотворчого мистецтва передбачає різноманітність кольорової палітри, що дарує людині радісний, світлий настрій.

Однак створюючи розпис писанки, слід враховувати важливість певного кольору, а саме:

- червоний колір символізує добро, щастя, радість життя;

- зелений - це колір пробудження природи, який також означає гарний врожай;

- блакитний - світлий і прозорий колір, який застосовують у фарбуванні неба, повітря, а також означає здоров'я;

- бурий, коричневий кольори символізують землю і приховану життєдайну силу;

- чорний - темний, важкий колір, який понижує настрій, колір всього невідомого і таємного.

Таким чином, використання різноманітних кольорів у писанкарстві традиційно символізує родинне щастя, мир, добробут.

На практичних заняттях 3 навчальної дисципліни “Живопис" в різні історичні періоди застосовується певна кольорова палітра.

Так, використання певного кольору в іконописі, який несе особливий зміст, має канонічну важливість. Наприклад, золотий колір символізує Бога, Божественну енергію, красу і пишність Царства Небесного. Жовтий колір, який в іконописі часто замінює золотий, - це колір вищої влади ангелів. Пурпурний або багряний застосовувався у візантійській культурі як колір у фарбуванні одягу Богоматері. Червоний колір символізував перемогу життя над смертю, тобто Воскресіння. Червоний фон на іконі передбачав торжество вічного життя. В іконописі білий колір символізує чистоту, простоту і святість, зображують ним Божественне світло. Використання синього і блакитного кольорів передбачає символ безмежності неба, вічного світу, також це колір Богоматері. Різдвяні сцени традиційно фарбувалися зеленим кольором, адже 


\section{“КОЛЬОРОЗНАВСТВО” У ПРОФЕСІЙНОМУ СТАНОВЛЕННІ МАЙБУТНЬОГОУЧИТЕЛЯ МИСТЕЦЬКИХ ДИСЦИПЛІН}

це символ вічного оновлення. Коричневий - це колір тимчасового і тлінного. В іконописі чорний колір прийнято мати на увазі як колір зла i смерті.

У зв'язку з цим дослідник М. Волосюк висловлює думку про те, що “в залежності від історичного, суспільного й культурного етапу розвитку людини для кожного кольору є важливим процес сприймання, адже колір не тільки викликає велику радість, діючи кожним своїм відтінком на нервові клавіші, він $є$ джерелом емоційної активності й додатковим стимулом пізнавального процесу" [2, 63-65]. Таким чином, символіка кольорів в іконописі має змістовний, багатогранний характер.

Аналізуючи змістову наповненість навчальної дисципліни “Кольорознавство”, можемо сформулювати окремі аспекти впливу дизайнерської освіти у професійної підготовки майбутніх фахівців. Завдяки методичним обгрунтуванням та систематизації означеної навчальної дисципліни мистецькі дисципліни 3 дизайну сприяють сучасному промисловому виробництву, визначенню компонентів образотворчого мистецтва, на основі яких можна розв'язати будь-які завдання, а відповідно і визначити педагогічні умови [5].

Отже, проаналізувавши наукові праці 3 означеної проблеми, можемо визначити методологічні підходи в освітньому процесі 3 навчальної дисципліни “Кольорознавство”, а саме:

1. Аксіологічний підхід застосовується у придбанні вмінь і навичок, заснованих на традиційності певної дисципліни, як здатність до сприймання, інтерпретації й оцінювання явищ образотворчого мистецтва; ціннісна художня орієнтація учнів, емоційно-естетичний досвід.

2. Системний підхід забезпечує розгляд підготовки майбутніх учителів мистецьких дисциплін як цілісної системи, яка має змістові, структурні й функціональні зв'язки.

3. Компетентісний підхід передбачає формування у студентів здатностей до компетентісного здійснення художньопедагогічної діяльності, забезпечує здатність до творчої і продуктивної самореалізації у самостійній праці.

4. Інтегративний підхід забезпечує концептуальні зв'язки між різними галузями знань, внутрішню їх взаємодію та взаємопроникнення, що надає можливість з різних сторон пізнати певне явище, поняття, досягти цінність знань.

5. Креативний підхід передбачає організацію процесу підготовки майбутніх учителів 3 предметно-змістового аспекту на особистість студента, що проявляється у ціннісно-смисловій інтерпретації навчальної діяльності.

Таким чином, нами були визначено наукові підходи, які застосовуються у навчальному процесі з дисципліни “Кольорознавство”. Практичне опанування основами “Кольорознавство” значно прискорить оволодіння студентами навичками і вміннями кольору в середовищі, а значить у професійному становленні майбутнього учителя мистецьких дисциплін.

Висновки та перспективи подальших наукових розвідок. Узагальнюючи вищезазначене, можемо стверджувати, що, вивчаючи навчальну дисципліну “Кольорознавство”, майбутній учитель мистецьких дисциплін повинен оволодіти знаннями про колір, адже у професійному становленні він повинен вміти застосовувати знання на практичних заняттях з дисциплін образотворчого мистецтва, а саме: “Живопис“, “Декоративноприкладне мистецтво”, “Етнодизайн”, “Основи моделювання одягу”, “Інтер'єрний дизайн” та “Флористичний дизайн”.

Перспективою подальшого розгортання досліджуваної проблеми є розробка інноваційних форм, методів у викладанні навчальної дисципліни “Кольорознавство” та впровадження у професійну підготовку майбутніх учителів образотворчих дисциплін 3 метою формування у них мистецького аспекту як важливого критерію загальнокультурної компетентності людини.

\section{ЛІТЕРАТУРА}

1. Бичкова Л. Колористична культура античного світу. Навчальний посібник. Київ: Вища школа, 2003. 135 с.

2. Волосюк М. Символіка кольорів ікони. Наука $i$ життя: сучасні тендениії, інтеграція у світову наукову думку. 2018. С.63-85.

3. Губаль Б. Композиція в дизайні. Одно-, дво- і тривимірний простір: Навчальний посібник. За ред. проф. С. А. Антоновича. Тернопіль: "ПЦ Матвей”, 2011. $240 \mathrm{c}$.

4. Декоративно-ужиткове мистецтво. Словник. Т. 1. За ред.. Я. П. Запаско. Львів: Афіша. 2000. 364 с.

5. Дизайн. Словник-довідник. Ін-т проблем сучасного мистецтва НАМ України. За ред. М.І. Яковлева. Київ: Фенікс, 2010. 384 с.

6. Крижанська О. Яким буває червоне? Синонімічні кольороназви в українській мові. 2001. № 2(24). С. 22-24.

7. Печенюк. Т. Кольорознавство. Підручник для студентів. Київ: Грані, 2010. 192 с.

8. Прищенко С. Кольорознавство: навчальний посібник. За ред. проф. С. А. Антоновича. Київ: Альтерпрес, 2010.334 с.

\section{REFERENCES}

1. Bychkova, L. (2003). Kolorystychna kultura antychnoho svitu [Coloristic culture of the ancient world]. A textbook. Kyiv, 135 p. [in Ukrainian]. 

ДОПЕДАГОГІЧНОЇ ДІЯЛЬНОСТІ

2. Volosyuk, M. (2018). Symvolika koloriv ikony. Nauka i zhyttya: suchasni tendentsiyi, intehratsiya u svitovu naukovu dumku [Symbolism of the colors of the icon. Science and life: modern trends, integration into world scientific thought]. pp. 63-65. [in Ukrainian].

3. Gubal, B. (2011). Kompozytsiya v dyzayni. Odno-, dvo- $\mathrm{i}$ tryvymirnyy prostir [Composition in design. One-, two- and three-dimensional space]. A textbook. For ed. E.A. Antonovich. Ternopil, 240 p. [in Ukrainian].

4. Dekoratyvno-uzhytkove mystetstvo (2000). [Decorative and applied arts]. Dictionary. (Ed.). J.P. Zapasko. Lviv, 364 p. [in Ukrainian].
5. Dyzayn. Slovnyk-dovidnyk (2010). [Design. Dictionary-reference. Institute of Contemporary Art Problems of the National Academy of Sciences of Ukraine]. (Ed.). E. Yakovleva. Kyiv, 384 p. [in Ukrainian].

6. Kryzhanska, O. (2001). Yakym buvaye chervone? Synonimichni koloronazvy $\mathrm{v}$ ukrayinskiy movi [What is red like? Synonymous color names in the Ukrainian language]. No. 2 (24) pp. 22-24. [in Ukrainian].

7. Pechenyuk, T. (2010). Koloroznavstvo [Color science]. Textbookfor students. Kyiv, 192 p. [in Ukrainian].

8. Pryshchenko, S. (2010). Koloroznavstvo [Color science]. A textbook.(Ed.). E.A.Antonovich. Kyiv, 334 p. [in Ukrainian].

Стаття надійшла до редакції 09.02.2021

УДК 378.147.227

DOI:

Василь Гуменюк, кандидат педагогічних наук, в. о. доцента кафедри медицини катастроф та військової медицини Львівського національного медичного університету імені Данила Галицького

\section{МОЖЛИВОСТІ ІНТЕРНЕТ-ПРОСКТУВАННЯ ЯК ЗАСОБУ ПІДГОТОВКИ МАГІСТРІВ МЕДИЦИНИ ДО ПЕДАГОГІЧНОЇ ДІЯЛЬНОСТІ}

У сучасних умовах студенти закладів вищої медичної освіти вже не просто пасивно сприймають нову інформацію з мережі Інтернет, а й є активними суб'єктами власної освіти і професійної діяльності. Це вимагає зміни підходу до організаџї підготовки майбутніх магістрів медицини до педагогічної діяльності і трансформації освітнього процесу з рівня “пасивного споживання” на рівень “активного перетворення інформачї̈”.

У межах статті розглянуто Інтернет-проєктування в контексті підготовки магістрів медицини до педагогічної діяльності як навчальний модуль, шүо дає змогу студентам-медикам оволодівати як професійними, так і загальнокультурними, надпрофесійними компетенціями, а викладачеві - здійснювати педагогічну супервізію діяльності студентів; має яскраво виражену спрямованість на вивчення, перетворення $i$ вдосконалення студентами сучасного сочіального Інтернет-середовища шляхом практичного застосування зазначених компетенцій.

Ключові слова: магістри медицини; Інтернет-проєктування; заклади вищої медичної освіти; підготовка до педагогічної діяльності.

Jim. 10.

Vasyl Humeniuk, Ph.D.(Pedagogy), the Officer-in-Charge of Associate Professor of the Catastrophe Medicine and Military Medicine Department of Lviv Danylo Halytskiy National Medical University

\section{POSSIBILITIES OF INTERNET DESIGNING AS A MEAN OF TRAINING OF MASTERS OF MEDICINE FOR PEDAGOGICAL ACTIVITY}

In modern conditions students of higher medical education institutions not only passively perceive new information from the Internet, but are also active subjects of their own education and professional activity. This requires a change in the approach to the organization of training of future masters of medicine for pedagogical activity and the transformation of the educational process from the level of "passive consumption" to the level of "active transformation of information".

The article considers Internet designing in the context of training masters of medicine for pedagogical activity as an educational module that allows medical students to master both professional and cultural, supraprofessional competencies, and for the teacher - to carry out pedagogical supervision of the students' activity; has a strong focus on the study, transformation and improvement of the modern social Internet environment through the practical application of these competencies by students.

The key material result of Internet designing is an Internet resource that solves the stated social (professional) problem at the orientation stage. It is valuable for the development of modern Internet space, because it increases the share of useful content on the Internet. The personal results of the participants are also important. During the implementation of Internet projects, masters of medicine show initiative and independence, learn to organize their 